T. Momot, D. TumietTo, R. TESLENKo

\title{
BLOCKCHAIN TECHNOLOGY AS AN INNOVATIVE INSTRUMENT OF DIGITAL ECONOMY: TECHNOLOGY ESSENCE, WORLD EXPERIENCE AND IMPLEMENTATION PROBLEMS
}

The subject matter of the article is the substantiation of the problems and perspectives of the introduction of Distributed Ledger Technologies (DLT) / Blockchain in the public and private sectors as a modern digital economy instrument. The goal of the work is to substantiate the scientific and methodical principles of implementing the technologies of distributed DLT / Blockchain registers. The following tasks were solved in the article: the notion of Distributed Ledger Technologies (DLT) and Blockchain is defined; types of Distributed DLT Registries are presented in the form of a classification with a distinction of features and possibilities of application of each type; the general scheme of work is described and the specific features of the Blockchain technology are systematized; the features and directions of the use of intelligent contracts (smart contracts) based on the technology of blockchain are singled out; the international experience of government initiatives and pilot projects of the blockade technology application has been analyzed; the analysis of the domestic experience of practical application of Blockchain technologies in the public and private sectors and the perspective areas for the future application of technologies of the distributed DLT registries are identified; according to the international analytical agencies research results, the obstacles of the Blockchain technologies implementation in the public and private sectors are systematized. The following methods are used: abstract-logical analysis, theoretical generalization, system and statistical analysis. The following results were obtained. The concept of technologies of distributed DLT / Blockchain registries is disclosed. The availability of the system is based on open, private and federal DLTs. The specific features of DLT / Blockchain distributed registry technologies include centralization, involvement of a large number of participants to achieve consensus, use of cryptography and digital signatures, almost impossible to change chronological records, the convenience of tracking and verifying information, and the ability to program. The international experience of using Blockchain technology in countries such as the Great Britain, Georgia, Estonia, the USA, the United Arab Emirates, Italy has been researched. Examples of practical implementation of DLT / Blockchain registry technology in Ukraine are considered. The main obstacles to implementing distributed DLT / Blockchain registries in the public sector are regulatory restrictions and technology immaturity. The obstacles to the introduction of block technologies in the private sector are identified. Conclusions: It is proved that the distributed DLT registry technology has a significant potential for development for the future digital economy. Nevertheless, there are a number of barriers to their full use in the public and private sector, which requires further study by experts.

Keywords: Distributed Ledger Technologies (DLT); Types of Distributed Ledger Technologies Blockchain; Intelligent Contract; specific features of Distributed Ledger Technologies (DLT).

\section{Introduction}

Comprehensive corruption is at the same time the cause, effect and factor, accompanies an opaque society relations system with inefficient state market mechanisms and distorted conditions for doing business [1]. Moreover, any abuse of entrusted power for the sake of obtaining one's own benefit may occur not only as a result of actions of state employees, politicians and bureaucrats, but also representatives of the business environment. So, on the one hand, a company can promote its own business interests, interacting illegally with government officials, and on the other, employees of the company, as well as government officials, may be corrupt and misuse their official capacity [2]. This all leads to the formation of various unprofitable for society shadow phenomena in the economy. Effective in combating such negative manifestations are modern digital tools, one of which is new, but promising blockchain technology. Decentralized, secure, well-designed blockchain-based system can reduce costs and increase the speed of information transfer, eliminate intermediaries, ensure transparency and enable detailed tracking of business processes in the public and private sectors.

Gartner analysts [3] predict that blockchain will add more than 3 billion dollars to the business value annually. By $2030,10 \%$ to $20 \%$ of global economic infrastructures will work with systems that will use blockade as a fundamental technology for business. It is expected that by 2025 , the cost of a business that will operate at the expense of blockchain will increase by more than 176 billion dollars, and by 2030 this amount will exceed 3.1 trillion dollars

According to experts from the World Economic Forum, by $2027,10 \%$ of world GDP will be allocated to the blockchain technology [4].

All this testifies to the urgency and the necessity of studying the essence, experience of use and problems on the way of introduction of blockchain technologies as a modern tool of the economy.

\section{The analysis of recent literary sources}

The basic concept of the blockchain technology came in 2008 and was first applied in practice in 2009 by launching bitcoin cryptographic. Since then, many studies have been devoted to this technology, including the works of A. Genkin and O. Mikheev [5], D. Tapscott and A. Tapscott [6], S. Melani [7], N. Popper [8] and others. Also worth of separate consideration are examples of the practical application of blockchain by private companies and government structures, sociological and other studies of world expert analytical organizations.

\section{The goal and objectives}

The purpose of the research is to substantiate the scientific and methodological principles of the 
implementation of Distributed Ledger Technologies (DLT) / blockchain technology, which, according to international experience, enables transactions to be carried out in complete safety with the involvement of a large number of objects and without the need for intermediaries, using the mathematical apparatus and technologies to ensure mutual trust. Achievement of the set purpose has led to the solution of such problems as: the concept of technology of the distributed register DLT within the blockchain limits is considered; types of distributed DLT registries are presented in the form of a classification with a distinction of features and possibilities when applying each type; the general scheme of work is described and the specific features of the blockade technology are systematized; the features and scope of the use of intelligent contracts (smart contracts) based on the blockchain technology are singled out; the international experience of government initiatives and pilot projects using the blockchain technology are analyzed; the analysis of the domestic experience of practical application of blockchain technologies in the public and private sectors and the perspective areas for the future application of technologies of the distributed DLT registry are identified; according to research results of international analytical agencies, obstacles to the implementation of blockchain technologies in the public and private sectors are systematized.

\section{Materials and methods}

The theoretical and methodological basis for the study was scientific works and informational and analytical materials of leading domestic scientists and foreign economic scientists in the implementation of DLT / blockchain distributed registries in the public and private sectors as a modern digital economy tool. In the course of the study, the following methods were used: abstract-logical analysis - for theoretical generalization and justification of the directions and results of the study; theoretical generalization - to identify and systematize the specific features of technologies of distributed DLT / blockchain registries, highlighting the scope of application of reasonable contracts; system and statistical analysis - for the analysis of international and domestic

Table 1. Types of distributed registries DLT experience in the practical implementation of blockchain technologies in the public and private sectors.

\section{The results of the study}

The blockchain technology became widely known not immediately, but only after the popularization of bitcoin, which in turn was a response to the global financial crisis of 2008-2009. The concept of bitcoin was published by the author or, more precisely, by a group of authors under the pseudonym Satoshi Nakamoto [9] in 2008, and was first put into practice in 2009 with the first block created by launching a Bitcoin cryptocurrency.

Distributed ledger technology (DLT) is an information storage technology whose key features are sharing and synchronization of digital data in accordance with a consensus algorithm, the geographical distribution of equivalent copies at various points around the world, and the absence of a central administrator. Blockchain is a kind of distributed ledger, but not every DLT is a blockchain.

Blockchain is a distributed database technology that allows to create a digital transaction register and share them within a distributed network of devices. Through the use of cryptography, each network participant manages the registry without centralized administration. They use independent computers (nodes) to record, share, and synchronize transactions in their respective electronic ledger (registries). The blockchain organizes data into blocks that are linked to each other in add-only mode. A node in the context of a cryptocurrency and DLT as a whole are devices with software installed on them that are combined into a common network in order to jointly ensure the operation of a distributed database. The whole system is described as a "system without trust", so that all nodes must come to a consensus to confirm the correct information. Transactions in the blockchain network occur 24/7. The system allows the exchange of digital assets in real time between two unrelated participants without a central counterparty and ensures their transparency and minimizes risks. Such operations are registered in a decentralized public distributed database, allowing network users to control their transactions and data.

By accessibility system is divided into open, private, and federated DLT (Table 1).

\begin{tabular}{|c|c|c|}
\hline DLT type & Features & Opportunities after applying \\
\hline $\begin{array}{l}\text { Open (public) DLT- } \\
\text { modern public records, } \\
\text { based on the algorithms of } \\
\text { consensus with open source }\end{array}$ & $\begin{array}{l}\text { - anyone can join the system, for example, run a full } \\
\text { node; } \\
\text { - anyone in the world can send transactions through } \\
\text { the network and wait for their inclusion in the } \\
\text { blockade, if they are valid; } \\
\text { - anyone can read the transaction in the block } \\
\text { browser; } \\
\text { - transactions are transparent but anonymous; } \\
\text { - do not allow anyone with Internet access to } \\
\text { participate - in the process of verifying transactions; } \\
\text { are faster and more confidential; } \\
\text { - mainly used in the banking sector (consensus is } \\
\text { controlled by pre-selected nodes: for example, a } \\
\text { consortium of } 15 \text { financial institutions, each of which } \\
\text { holds a node, and } 10 \text { of them must sign each block) }\end{array}$ & $\begin{array}{l}\text { - potentially can destroy existing business } \\
\text { models by refusing to mediate; } \\
\text { - lack of infrastructure costs: there is no } \\
\text { need to maintain servers or system } \\
\text { administrators, which drastically reduces the } \\
\text { cost of creating and running decentralized } \\
\text { applications (dApps) }\end{array}$ \\
\hline
\end{tabular}


The end of the Table 1

\begin{tabular}{|c|c|c|}
\hline $\begin{array}{l}\text { Federated distributed } \\
\text { registries, or blockchain- } \\
\text { consortia - the systems that } \\
\text { operate under the leadership } \\
\text { of the group }\end{array}$ & $\begin{array}{l}\text { - do not allow anyone with Internet access to } \\
\text { participate in the process of verifying transactions; } \\
\text { - are faster and more confidential; } \\
\text { - mainly used in the banking sector (consensus is } \\
\text { controlled by pre-selected nodes: for example, a } \\
\text { consortium of } 15 \text { financial institutions, each of which } \\
\text { holds a node, and } 10 \text { of them must sign each block) }\end{array}$ & $\begin{array}{l}\text { - reduces transaction costs and data } \\
\text { abundance; } \\
\text { - replaces obsolete systems, simplifies } \\
\text { workflow and reduces manual labor; } \\
\text { - complements the ecosystem, but does not } \\
\text { destroy it }\end{array}$ \\
\hline $\begin{array}{l}\text { Private blockchains are not } \\
\text { DLTs, since permissions } \\
\text { are stored centrally for one } \\
\text { organization. }\end{array}$ & - reading permissions may be public or restricted & \\
\hline
\end{tabular}

In today's conditions and at the current speed of digital technologies development, blockchain as an independent unit of scientific and technical progress is gradually going beyond the financial market framework and the cryptocurrency sphere.

Blockchain is a distributed database that stores information about all transactions of participants in the system in the form of a chain of blocks. Every blockchain user has an access to the registry. They all act as a collective notary who confirms the information in the database. The general scheme of this technology is shown in fig. 1.

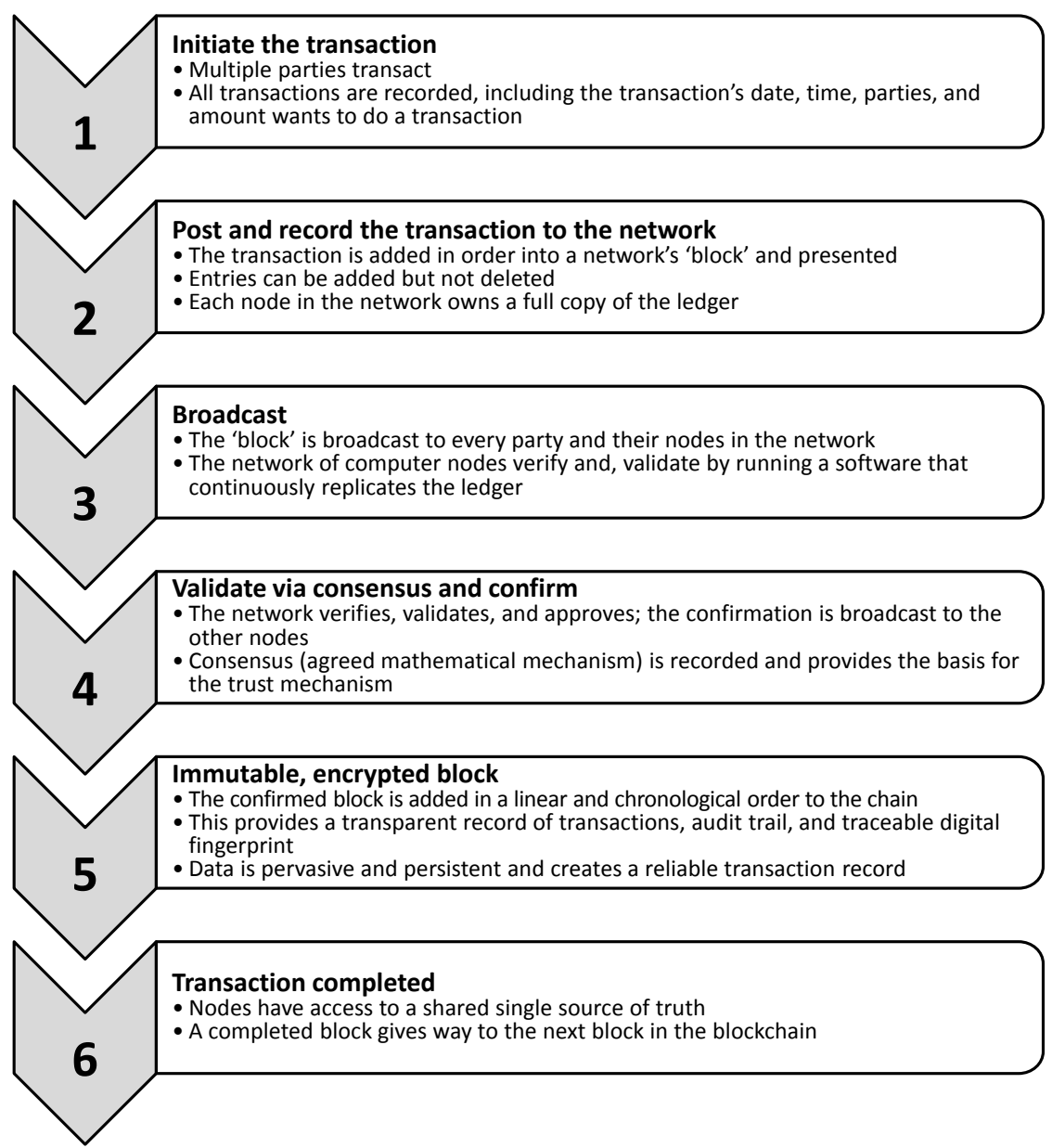

Fig. 1. The general scheme of blockchain technology work (KPMG) [10]

Thus, blockchain is characterized by the following specific features:

- the blockchain is digitally distributed among multiple computers in almost real-time mode: it is decentralized, and a copy of all records is available to all users and participants of the peer-to-peer network, which eliminates the need to have centralized authorized bodies, such as banks, as well as trust intermediaries, such as brokerage firms;
- to achieve consensus, the blockchain attracts many network participants whose computers are used to authenticate and test each new block (for example, to ensure that a single transaction does not take place several times), and new blocks are accepted by the network if most of them agree with their admissibility its members;

- the blockchain uses cryptography and digital signatures to verify identity: transactions can be traced to cryptographic identification data obtained theoretically 
anonymously, but can also be attached to real identification data after a certain engineering analysis;

- the blockchain has mechanisms that make it difficult (but not impossible) to change historical records: even though the blockchain allows you to read all the data and add new ones, those records that already exist cannot theoretically be corrected, unless the embedded protocol rules allow changes (for example, if more than $50 \%$ of network members agree on this);

- a time stamp is added to blockchain-based transactions, which makes it easy to track and verify information;

- the blockchain is programmed: the instructions embedded in the blocks allow performing transactions or other actions only under certain conditions and can be accompanied by additional digital data [11].

Smart contracts is one of the blockchain applications, which is the most attractive in the fight against corruption. A smart contract is a computer program with a predetermined and irreversible action that is automatically executed under certain conditions. This is an agreement between two parties, which is stored on the blockchain. Smart contracts allow you to automate payments and transfers of currency or other assets under the agreed terms. As soon as a condition is set in a reasonable contract, it is executed automatically and the assets (for example, cash, digital currency, ownership, data) are exchanged between the parties to the contract, after which the transaction is replicated and checked on a block chain. Smart contracts allow you to swap an asset if third parties are not aware of the transfer. This makes it possible to disintegrate the entire legal system and create a new form of virtual transactions. In fact, being code fragments that automatically perform actions under given conditions, smart contracts cannot yet be considered as regular contracts from a legal point of view. However, they can be used as evidence of a solution to a particular problem and numerous industries are exploring the potential application of such contracts. However, experts see widespread use of reasonable contracts only in the long term, because, despite certain attempts to implement them, this technology is experimental and not yet ripe for the emergence of the first market products $[12 ; 13]$.

However, the blockchain has already gained popularity for working with smart contracts - Ethereum. It's a platform for creating decentralized online applications based on blockchain technology. The Ethereum distributed network based on the blockchain has all the key advantages of this technology, such as security, irremovability, protection against corruption, hacker attacks and other unauthorized actions. Therefore, besides the fact that Ethereum gives users the opportunity to conduct any financial transactions with any assets, without resorting to the services of intermediaries, it also provides complete reliability of the transaction and protection against fraud. The main value of the Ethereum network is that it allows you to create multiple applications on a single platform, and is able to decentralize any centralized system. Decentralized applications can really make a real revolution in almost every sector of the economy.
It is assumed that many new functions based on blockchain will arise in the sphere of legal services, which will have to be supported by modern laws and institutions. For example, intellectual property rights that can be publicly accessible through a distributed register, land cadastre and document management, public records for voter registration and census data.

Below are examples of some government initiatives and pilot projects using blockchain technology in a number of countries.

Blockchain as a service has become available through the digital market of the UK government. With this service, government agencies can experiment, build and deploy digital services based on distributed registry technologies. In 2016, the report of the Great Britain Government Office for Science [14] noted the benefits of using distributed registry technology in the public and private sectors. It is believed that the blockchain can help in areas such as reducing fraud and corruption, protecting critical infrastructure and registering assets.

Georgia began using the blockchain technology in the land registry to verify land ownership and verify real estate transactions. This has created a safe and defenseless system, increases transparency, reduces costs and prevents corruption.

Estonia is considered the leading country in adopting blockchain technology in key areas such as health, voting and identity management. She has been testing this technology since 2008 and since 2012 has been actively using it in various registries. Already, citizens and residents of Estonia are issued cryptographically protected digital ID cards, reinforced by the blockchain infrastructure, which allows access to various state services. On the blockchain platform, citizens can check the integrity of records stored in state databases and control access to them.

Blockchain and smart contracts are closely monitored by the US regulatory government. In 2016, Delaware became the first state to implement blockchain technology. The technology is used to store contracts and other corporate data in a distributed registry, allowing companies and agencies to store their documents in several places. This will ensure their security and will automate access for voters, shareholders and employees. The public archives of the state of Delaware will be among the first to use the blockchain to archive and encrypt government documents.

The Dubai Economic Development Department (United Arab Emirates) will fully transfer registration and licensing of enterprises to the blockchain. Interest in technology also shows the largest bank in Dubai. Together with IBM, it is planned to transfer trade and logistics operations to the blockchain, as well as replace paper contracts with smart contracts. This will minimize the participation of officials in government, make its economy and management more transparent, and therefore create conditions under which corruption cannot develop, and citizens can be served as quickly and efficiently as possible [15]. 
The Blockchain government service concept of Italy is to improve efficiency, security, transparency, and participation, while giving every government agency the ability to manage its processes using its own technological "registry", regardless of the processes and technologies of any other state entity.

Singapore, Finland, Switzerland and the list of such countries will only increase in the future.

Ukraine belongs to one of the first countries in the implementation of the distributed DLT registry technology. Back in 2015, the decentralized electronic system of state property auctions E-Auction 3.0 was launched here. The system is the world's first example of how a state uses a decentralized system for the privatization and leasing of state property and licensing. The memorandum on the implementation of the system was signed by the governors of several regions with the Innovation and Development Fund (IDF Reforms Lab). The founder of the foundation is ex-deputy justice minister of Georgia Giorgi Vashadze. Today, in EAuction 3.0 they plan to join the Deposit Guarantee Fund for individuals, regional administrations and the State Committee for Land Relations.

In October 2017, the State Service of Ukraine for Geodesy, Cartography and Cadastre joined the development of technology. The blockchain was introduced for the transactions "Registration of the land plot" and "Provision of information from the land cadastre". The blockchain should exclude the possibility of substitution of data in the registry and all operations in the inventory can be tracked online. Transparency International, a public international organization for the fight against corruption, and anyone interested will follow the order of using the technology. All land title documents will receive their QR code, which will encrypt information about the owner of the site, the size and location of the land plot. Technical implementation will provide one of the world leaders in the field of Blockchain - the BitFury company.

Moved to blockchain and OpenMarket - a stateowned enterprise created by the Ministry of Justice for the sale of seized property. In 2016, the State Property Fund began selling state-owned property through the electronic trading system OpenMarket. After the transition to the blockchain technology, anyone can check the chronology of actions performed during the auction. The activity of the auction system OpenMarket also provides BitFury infrastructure.

The Ministry of Infrastructure of Ukraine is also planning to introduce blockchain. Infrastructure Minister Volodymyr Yemelyan announced the launch of a largescale Blockchain4Ukraine initiative. On the basis of the technology, it is planned to create a register of investment objects in the field of infrastructure, transfer the register of bus routes to technology and launch a national travel reservation system on its basis. In the future - add air and rail traffic.

Among the first industries to be transferred to the blockchain in Ukraine are state registries, housing and public utilities, social insurance, health care, and energy [16].
A study by IBM [17] showed a wave of interest among government organizations around the world with DLT distributed registry technology. It is noted that the blockchain can positively affect their activities in many areas in the near future. However, by interviewing 200 officials from 16 countries, a report from IBM highlighted a number of barriers to the full implementation of the blockchain (fig. 2).

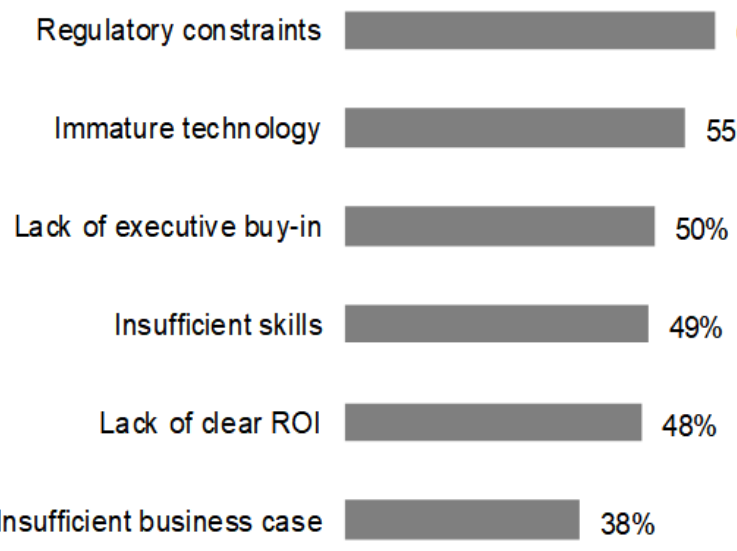

Fig. 2. Obstacles to blockchain implementation for government organizations (IBM) [17]

With a special distrust, the blockchain is perceived by the business. After all, it's business and the private sector of the economy as a whole that can often be the basic driving force for everyday use of the advantages of the DLT distributed database system in other areas. Although the blockchain by its definition should inspire confidence, but in reality, companies raise the issue of trust at every step. This problem is evidenced by a recent study from PwC [18], which reflects the results of a survey of 600 leaders from 15 countries (fig. 3 ).

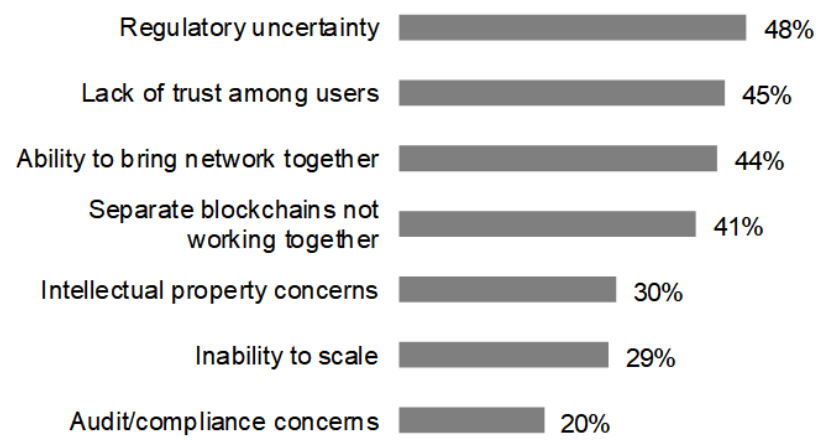

Fig. 3. Obstacles to blockchain implementation for business (PwC) [18]

As with any new technology, problems and doubts exist around the possibility of blockchain to ensure reliability, speed, security and scalability. Also, business is worried about the lack of standards and the potential incompatibility of various blockchains.

In a company that creates a blockchain for itself, there will undoubtedly be difficulties with internal use with the process of restructuring data in the new system and scaling. And yet, the company can independently set the rules and monitor their compliance with the blockchain, as it does in ERP (Enterprise Resource 
Planning) systems today. However, as noted by $\mathrm{PwC}$ experts, building a blockchain only for their own needs, an enterprise cannot fully realize all the benefits that can be obtained by investing in a blockchain. After all, this technology is really revealed only when various market participants use it to create a single platform. If a third party is involved in the blockchain alone, it will be impossible to establish the rules.

\section{Conclusions}

According to the results of the study, the technologies of the distributed DLT registry have a significant development potential for the future of the digital economy.

Relatively new distributed registry / blockchain technology - the data structure, allows to create a digital transactions register and share them within a distributed network of devices. Through the use of cryptography, each member of the network manages the register without centralized administration, provides an unprecedented level of integrity, security and reliability of information, reducing the risks associated with the existence of a single point of failure. This eliminates the need for intermediaries, reduces bureaucracy, reduces the level of corruption and ensures transparency in the provision of public services in the private sector. It also allows tracking transactions. Blockchain can be applied in practice in the following areas: state registers, financial and legal operations, logistics, voting, copyright, medicine, etc.

Despite the potential of technology, there is a certain number of barriers for its full implementation in the public and private sector, requiring further consideration by experts. At the level of governmental organizations, this is regulatory restrictions, immaturity of technology, lack of support from performers, insufficient level of technology skills, lack of understanding of the process of investment return, and a small number of successfully implemented projects. For representatives of the business environment, the obstacles to the use of technology are regulatory uncertainty, lack of trust, openness of personal data due to the possibility of network unification, technical impossibility for different chain of blocks to work together, intellectual property problems, impossibility of scaling, and problems with auditing / compliance.

\section{Список літератури}

1. Момот Т. В., Ващенко О. М., Тесленко Р. Ю. Тіньова економіка як загроза економічній безпеці України [Електронний ресурс]. Економіка та суспільство. 2018. № 15. C. 169-176. URL : http://www.economyandsociety.in.ua/journal/15_ukr/27.pdf (дата звернення: 20.08.2018).

2. Чех Н. О., Ващенко О. М. Корупція в бізнесі: корупційна поведінка у внутрішньо бізнесовому середовищі. Сучасний стан наукових досліджень та технологій в промисловості. 2018. № 2 (4). С. 57-62. DOI: https://doi.org/10.30837/25229818.2018.4.057.

3. Forecast: Blockchain Business Value, Worldwide, 2017-2030, URL : https://www.gartner.com/doc/3627117/forecast-blockchainbusiness-value-worldwide (last accessed 20.08.2018).

4. Deep Shift - Technology Tipping Points and Societal Impact. World Economic Forum Survey Report, URL: http://www3.weforum.org/docs/WEF_GAC15_Technological_Tipping_Points_report_2015.pdf (last accessed 20.08.2018).

5. Генкин А., Михеев А. Блокчейн: Как это работает и что ждет нас завтра. Москва : Альпина Паблишер, 2018.592 с.

6. Tapscott D., Tapscott A. Blockchain Revolution: How the Technology Behind Bitcoin Is Changing Money. Business, and the World. New York, 2016. 348 p.

7. Мелани С. Блокчейн. Схема новой экономики. Москва : Олимп-Бизнес, 2017. 240 с.

8. Поппер Н. Цифровое золото: невероятная история биткоина, или как идеалисты и бизнесмены изобретают деньги заново. Москва, Санкт-Петербург, Киев : Диалектика, 2016. 358 с.

9. Nakamoto S. Bitcoin: A Peer-to-Peer Electronic Cash System [Electronic resource]. 2008. URL : https://bitcoin.org/bitcoin.pdf (last accessed 20.08.2018).

10. Consensus- Immutable agreement for the Internet of value. URL : https://assets.kpmg.com/content/dam $/ \mathrm{kpmg} / \mathrm{pdf} / 2016 / 06 / \mathrm{kpmg}$ blockchain-consensus-mechanism.pdf (last accessed 20.08.2018).

11. Blockchain Enigma. Paradox. Opportunity. URL: https://www2.deloitte.com/content/dam/Deloitte/uk/Documents/ Innovation/deloitte-uk-blockchain-full-report.pdf (last accessed 20.08.2018).

12. Iansiti M., Lakhani K. R. The Truth About Blockchain. Harvard Business Review. Issue January-February. P. 118-127.

13. Белоусов П. Программы блокчейна: что препятствует массовому внедрению смарт-контрактов : веб-сайт. URL : http://www.forbes.ru/tehnologii/343843-programmy-blokcheyna-chto-prepyatstvuet-massovomu-vnedreniyu-smart-kontraktov (дата обращения: 20.08.2018).

14. Distributed Ledger Technology: beyond block chain [Electronic resource]. Government Office for Science. 2016. URL: https://assets.publishing.service.gov.uk/government/uploads/system/uploads/attachment_data/file/492972/gs-16-1-distributed-ledgertechnology.pdf (last accessed 20.08.2018).

15. Kwang T. W. How are governments using blockchain technology, URL : https://www.enterpriseinnovation.net/article/how-aregovernments-using-blockchain-technology-1122807855 (last accessed 20.08.2018).

16. Редих Э. Что такое Blockchain и где его применяют в Украине : веб-сайт. URL: https://biz.censor.net.ua/resonance/3061113/chto_takoe_blockchain_i_gde_ego_primenyayut_v_ukraine (дата обращения: 20.08.2018).

17. Building Trust in Government - Exploring the Potential of Blockchain, IBM Institute for Business Value, 2017, URL: https://public.dhe.ibm.com/common/ssi/ecm/gb/en/gbe03801usen/gbe03801usen-01_GBE03801USEN.pdf (last accessed 20.08.2018).

18. PwC's Global Blockchain Survey 2018, URL : https://www.pwccn.com/en/research-and-insights/publications/global-blockchainsurvey-2018/global-blockchain-survey-2018-report.pdf (last accessed 20.08.2018). 


\section{References}

1. Momot, T. V., Vashchenko, O. M., Teslenko, R. Yu. (2018), "The shadow economy as a threat to the economic security of Ukraine" ["Tinova ekonomika yak zahroza ekonomichnii bezpetsi Ukrainy"], Ekonomika ta suspilstvo, No. 15, P. 169-176, available at : http://www.economyandsociety.in.ua/journal/15_ukr/27.pdf (last accessed 20.08.2018).

2. Chekh, N. O., Vashchenko, O. M. (2018), "Corruption in business: corrupt behaviour inside business environment" ["Koruptsiia v biznesi: koruptsiina povedinka u vnutrishno biznesovomu seredovyshchi"], Innovative Technologies and Scientific Solutions for Industries, No. 2 (2), P. 57-62. DOI: https://doi.org/10.30837/2522-9818.2018.4.057.

3. Forecast: Blockchain Business Value, Worldwide, 2017-2030, available at: https://www.gartner.com/doc/3627117/forecastblockchain-business-value-worldwide (last accessed 20.08.2018).

4. Deep Shift - Technology Tipping Points and Societal Impact. World Economic Forum Survey Report, available at : http://www3.weforum.org/docs/WEF_GAC15_Technological_Tipping_Points_report_2015.pdf (last accessed 20.08.2018)

5. Genkin, A., Mikheev, A. (2018), Blockchain: How it works and what is waiting for us tomorrow [Blokcheyn: Kak eto rabotaet 1 chto zhdet nas zavtra], Moscow : Al'pina Pablisher, 592 p.

6. Tapscott, D., Tapscott, A. (2016), Blockchain Revolution: How the Technology Behind Bitcoin Is Changing Money, Business, and the World, New York, $348 \mathrm{p}$.

7. Melani, S. (2017), Blockchain The scheme of the new economy [Blokcheyn. Skhema novoy ekonomiki], Moscow : OlimpBiznes, $240 \mathrm{p}$.

8. Popper, N. (2016), Digital gold: an incredible history of Bitcoin, or how idealists and businessmen reinvent money [Tsifrovoe zoloto: neveroyatnaya istoriya bitkoina, ili kak idealisty i biznesmeny izobretayut den'gi zanovo], Moscow, Saint-Petersburg, Kiev : Dialektika, $358 \mathrm{p}$.

9. Nakamoto, S. (2008), "Bitcoin: A Peer-to-Peer Electronic Cash System", available at: https://bitcoin.org/bitcoin.pdf (last accessed 20.08.2018).

10. Consensus- Immutable agreement for the Internet of value, available at https://assets.kpmg.com/content/dam/kpmg/pdf/2016/06/kpmg-blockchain-consensus-mechanism.pdf (last accessed 20.08.2018).
11. Blockchain
Enigma.
Paradox.
Opportunity, available
at :

https://www2.deloitte.com/content/dam/Deloitte/uk/Documents/Innovation/deloitte-uk-blockchain-full-report.pdf (last accessed 20.08.2018).

12. Iansiti, M., Lakhani, K. R. (2017), "The Truth About Blockchain", Harvard Business Review, Issue January-February. P. 118127.

13. Belousov, P. (2017), "Blockchain programs: which hinders the massive deployment of smart contracts" ["Programmy blokcheyna: chto prepyatstvuet massovomu vnedreniyu smart-kontraktov"], available at: http://www.forbes.ru/tehnologii/343843programmy-blokcheyna-chto-prepyatstvuet-massovomu-vnedreniyu-smart-kontraktov (last accessed 20.08.2018).

14. Distributed Ledger Technology: beyond block chain. Government Office for Science. 2016, available at : https://assets.publishing.service.gov.uk/government/uploads/system/uploads/attachment_data/file/492972/gs-16-1-distributed-ledgertechnology.pdf (last accessed 20.08.2018).

15. Kwang, T. W. (2017), "How are governments using blockchain technology", available at: https://www.enterpriseinnovation.net/article/how-are-governments-using-blockchain-technology-1122807855 (last accessed 20.08.2018).

16. Redikh, E. (2018), "What is Blockchain and where it is used in Ukraine" ["Chto takoe Blockchain i gde ego primenyayut v Ukraine"], available at : https://biz.censor.net.ua/resonance/3061113/chto_takoe_blockchain_i_gde_ego_primenyayut_v_ukraine (last accessed 20.08.2018).

17. Building Trust in Government - Exploring the Potential of Blockchain, IBM Institute for Business Value, 2017, available at : https://public.dhe.ibm.com/common/ssi/ecm/gb/en/gbe03801usen/gbe03801usen-01_GBE03801USEN.pdf (last accessed 20.08.2018).

18. PwC's Global Blockchain Survey (2018), available at: https://www.pwccn.com/en/research-and-insights/publications/globalblockchain-survey-2018/global-blockchain-survey-2018-report.pdf (last accessed 20.08.2018).

Received 25.08.2018

\section{Вiдомості про авторів / Сведения об авторах / About the Authors}

Момот Тетяна Валеріївна - доктор економічних наук, професор, Харківський національний університет міського господарства імені О. М. Бекетова, завідувач кафедри фінансово-економічної безпеки, обліку і аудиту, Харків, Україна; еmail: tvmomot@gmail.com; ORCID ID: https://orcid.org/0000-0001-7397-3565.

Момот Татьяна Валерьевна - доктор экономических наук, профессор, Харьковский национальный университет городского хозяйства имени А. Н. Бекетова, заведующая кафедры финансово-экономической безопасности, учета и аудита, Харьков, Украина.

Momot Tetiana - Doctor of Sciences (Economics), Professor, O. M. Beketov Kharkiv National University of Urban Economy, Head at the Department of Financial and Economic Security, Accounting and Auditing, Kharkiv, Ukraine.

Туміетто Даніеле - корпоративний консультант $з$ цифрового управління процесами та документами для компаній та державних адміністрацій, експерт в органах законодавчого і технічного стандарту в національних організаціях (UNI / UNINFO), європейських (CE, CEN, CEF) та в усьому світі (ООН / СЕФАКТ, СЕК ООН, МСЕ), ад’юнкт-професор Університету Лінку (Link Campus University), Мілан, Італія; e-mail: tumietto@economisti.it; ORCID ID: https://orcid.org/00000003-0715-2288.

Тумиетто Даниеле - корпоративный консультант по цифровому управлению процессами и документами для компаний и государственных администраций, эксперт в органах законодательного и технического стандарта в национальных 
организациях (UNI / UNINFO), европейских (CE, CEN, CEF) и во всем мире (ООН / СЕФАКТ, ЕЭК ООН, МСЭ), адъюнктпрофессор Университета Линка (Link Campus University), Милан, Италия.

Tumietto Daniele - Corporate Consultant in the Digital Management of Processes and Documents for Companies and Public Administrations, Expert with the Legislative and Technical Standards Bodies in the National (UNI / UNINFO), European (CE, CEN, CEF) and Worldwide (UN / CEFACT, UNECE, ITU) Standard Organizations, Adjunct Professor at the Link Campus University in Rome, Milan, Italy.

Тесленко Роман Юрійович - Харківський національний університет міського господарства імені О. М. Бекетова, аспірант кафедри фінансово-економічної безпеки, обліку і аудиту, Харків, Україна; e-mail: roman.tslnk@gmail.com; ORCID ID: https://orcid.org/0000-0001-9008-2959.

Тесленко Роман Юрьевич - Харьковский национальный университет городского хозяйства имени А. Н. Бекетова, аспирант кафедры финансово-экономической безопасности, учета и аудита, Харьков, Украина.

Teslenko Roman - O. M. Beketov Kharkiv National University of Urban Economy, Post-Graduate Student at the Department of Financial and Economic Security, Accounting and Auditing, Kharkiv, Ukraine.

\section{ТЕХНОЛОГІЇ БЛОКЧЕЙН ЯК ІННОВАЦІЙНИЙ ІСНТРУМЕНТ ЦИФРОВОЇ ЕКОНОМІКИ: СУТНІСТЬ ТЕХНОЛОГІЇ, СВІТОВИЙ ДОСВІД ТА ПРОБЛЕМИ ВПРОВАДЖЕННЯ}

Предметом дослідження в статті є обгрунтування проблем та перспектив впровадження технологій розподілених реєстрів DLT / блокчейн в державному та приватному секторі як сучасного інструменту цифрової економіки. Мета роботи обгрунтування науково-методичних засад впровадження технологій розподілених реєстрів DLT / блокчейн. В статті вирішуються наступні завдання: розглянуто поняття технології розподіленого реєстру DLT за рамками блокчейна; подано види розподілених реєстрів DLT у вигляді класифікації з виокремленням особливостей та можливостей при застосуванні кожного виду; описано загальну схему роботи та систематизовано специфічні особливості технології блокчейн; виокремлено особливості та сфери застосування розумних контрактів (смарт-контрактів), заснованих на технології блокчейн; проаналізовано міжнародний досвід урядових ініціатив та пілотних проектів із використанням технології блокчейн; проведено аналіз вітчизняного досвіду практичного впровадження технологій блокчейн в державному та приватному секторі та виділені перспективні сфери для майбутнього застосування технологій розподіленого реєстру DLT; за результатами досліджень міжнародних аналітичних агенцій систематизовано перешкоди впровадження технологій блокчейн в державному та приватному секторі. Використовуються такі методи: абстрактно-логічний аналіз, теоретичного узагальнення, системного та статистичного аналізу. Отримано наступні результати: розкрито поняття технологій розподілених реєстрів DLT / блокчейн. За доступністю системи виділено відкриті, приватні і федеративні DLT. До специфічних особливостей технологій розподілених реєстрів DLT / блокчейн віднесено централізованість, залучення великої кількості учасників для досягнення консенсусу, використання криптографії та цифрових підписів, майже неможлива зміна хронологічних записів, зручність відстеження та перевірки інформації, можливість програмування. Досліджено міжнародний досвід використання технологій блокчейн в таких країнах як Великобританія, Грузія, Естонія, США, Об'єднані Арабські Емірати, Італія. Розглянуто приклади практичного впровадження технології реєстрів DLT / блокчейн в Україні. До основних перешкод впровадження розподілених реєстрів DLT / блокчейн в публічному секторі віднесено регуляторні обмеження та незрілість технології. Визначено перешкоди впровадження блокчейн технологій у приватному секторі. Висновки: доведено, що технології розподіленого реєстру DLT мають значний потенціал розвитку для майбутнього цифрової економіки. Не зважаючи на це, існує певна кількість бар'єрів для повноцінного їх застосування в державному та приватному секторі, що потребує подальшого вивчення експертами.

Ключові слова: технології розподілених реєстрів; види розподілених реєстрів DLT; блокчейн; розумні контракти (смарт-контракти); специфічні особливості технологій розподілених реєстрів DLT.

\section{ТЕХНОЛОГИИ БЛОКЧЕЙН КАК ИННОВАЦИОННЫЙ ИНСТРУМЕНТ ЦИФРОВОЙ ЭКОНОМИКИ: СУЩНОСТЬ ТЕХНОЛОГИИ, МИРОВОЙ ОПЫТ И ПРОБЛЕМЫ ВНЕДРЕНИЯ} \begin{tabular}{l} 
Предметом исследования в статье является обоснование проблем и перспектив внедрения технологий распределенных \\
реестров DLT / блокчейн в государственном и частном секторе как современного инструмента цифровой экономики. Цель \\
работы - обоснование научно-методических основ внедрения технологий распределенных реестров DLT / блокчейн. В \\
статье решаются следующие задачи: рассмотрены понятия технологии распределенного реестра DLT за рамками блокчейна; \\
представлены виды распределенных реестров DLT в виде классификации с выделением особенностей и возможностей при \\
применении каждого вида; описана общая схема работы и систематизированы специфические особенности технологии \\
блокчейн; выделены особенности и области применения умных контрактов (смарт-контрактов), основанных на технологии \\
блокчейн; проанализирован международный опыт правительственных инициатив и пилотных проектов с использованием \\
технологии блокчейн; проведен анализ отечественного опыта практического внедрения технологий блокчейн в \\
государственном и частном секторе и выделены перспективные сферы для будущего применения технологий \\
распределенного реестра DLT; по результатам исследований международных аналитических агентств систематизированы \\
препятствия внедрения технологий блокчейн в государственном и частном секторе. Используются следующие методы: \\
абстрактно-логический анализ, теоретического обобщения, системного и статистического анализа. Получены следующие \\
результаты: раскрыто понятие технологий распределенных реестров DLT / блокчейн. В зависимости от доступности \\
системы выделено открытые, частные и федеративные DLT. К специфическим особенностям технологий распределенных \\
реестров DLT / блокчейн отнесены централизованность, привлечение большого количества участников для достижения \\
\hline
\end{tabular} 
консенсуса, использование криптографии и цифровых подписей, почти невозможное изменение хронологических записей, удобство отслеживания и проверки информации, возможность программирования. Исследован международный опыт использования технологий блокчейн в таких странах как Великобритания, Грузия, Эстония, США, Объединенные Арабские Эмираты, Италия. Рассмотрены примеры практического внедрения технологии реестров DLT / блокчейн в Украине. К основным препятствиям для внедрения распределенных реестров DLT / блокчейн в публичном секторе отнесены регуляторные ограничения и незрелость технологии. Определены препятствия внедрения блокчейн технологий в частном секторе. Выводы доказано, что технологии распределенного реестра DLT имеют значительный потенциал развития для будущего цифровой экономики. Несмотря на это, существует определенное количество барьеров для полноценного их применения в государственном и частном секторе, что требует дальнейшего изучения экспертами.

Ключевые слова: технологии распределенных реестров; виды распределенных реестров DLT; блокчейн; умные контракты; специфические особенности технологий распределенных реестров DLT. 